\title{
The Schooling Return on the Non-farm Income of Chinese Western Rural Labors
}

\author{
Luan Jiang $^{1}$, Li Tingting ${ }^{2, *}$, Chen Jiancheng $^{3}$, Guo Pei $^{2}$ \\ ${ }^{1}$ Department Economics, Party School of CPC Tianjin Municipal Committee, Tianjin, China, \\ ${ }^{2}$ Economic \& Management School, China Agricultural University, Beijing, China \\ ${ }^{3}$ Economic \& Management School, Beijing Forestry University, Beijing, China \\ *Corresponding author; e-mail:csver@qq.com.
}

Keywords: Non-farm Income; Schooling Return; Mincer Income Model

\begin{abstract}
Education plays an important role in improving Chinese rural laborers' non-farm incomes. However, several analyses have shown that the returns on schooling are very low in the western region, which could have a negative influence on improving farmers' incomes and the even development of the national economy. No previous research has addressed this question. This paper is based on large samples from a rural household survey, using Mincer income model to estimate the schooling return. The results showed the following: The Mincer schooling returns were estimated to range from 2.7 to $3.9 \%$ using parametric methods. This result is lower than that in most recent studies.
\end{abstract}

\section{Introduction}

Education plays an important role in improving rural laborers' non-farm incomes. Rural laborers can gain skills and opportunities through education. Many researchers have analyzed the returns on schooling and found that it was effective in improving non-farm incomes. Yao and Zhang (2004) estimated that schooling among the rural Chinese had a $4 \%$ return; the percentage was about $6.3 \%$ in Brauw and Rozelle's (2006) research; it was 7.5\% according to the research conducted by the Han and Guo (2007); and it was 5.3-6.8\% in Wang and Cai’s (2008) research.

However, in the rural areas of the west, the level of schooling returns is very low due to the underdeveloped economy and the condition of the education system. This will seriously threaten Chinese economic development. Cao et al. (2009) concluded that the schooling return in the northwest area was 1.1-5.5\%; Li (2003) analyzed the eastern, central, and western rural schooling returns separately and found that the schooling returns of secondary education and vocational education in the western area were $7 \%$ and $13 \%$ lower than the levels in the eastern part of the country, respectively. This phenomenon will enlarge the regional gap in Chinese regional economic development and income level. According to data from the State Statistical Bureau, the difference between eastern and western rural income per capita has widened from 1386 RMB in 2005 to 3470 RMB in 2011 (taking the price level in 2005 as the base price), an increase of 150\%.

\section{The Data and Model}

The data we used to analyze this issue were from a survey of rural laborers in the west of China conducted by the author in 2012.

Most researchers use the Mincer earnings model to analyze the returns on education. The basic model equation is

$$
\ln y=\alpha+\beta_{1} D+\beta_{2} \exp +\beta_{3} \exp ^{2}+\mu
$$

where $\mathrm{y}$ is the laborer's income, $\mathrm{D}$ is years of education, exp is years of experience, and $E(\mu)=0$. Using the regression method, we can estimate the parameters in equation (1). Then, $\beta_{1}$ gives the returns on education. Previous researchers have focused on the problem of endogenous characteristics. The factors of ability bias are not measurable and are included in the error term $\mu$. 
However, they are closely correlated with the laborers' education and income, so that result is influenced by the biased estimator. Researchers have mainly used the proxy variables method, instrumental variables method, or Heckman two-step method to eliminate this bias (Li \& Heckman, 2004).

\section{Returns on education}

The results for the returns on education are presented in Table 1. The estimates of the returns on education using OLS from the Mincer earnings model was 3.4\%, meaning that the income of a laborer with one or more years of education would increase by $3.4 \%$. The gender, experience, health, skill-training, cultivated land area, self-employment, and work region also had effects on non-farm income. However, the estimates by OLS always had an upward bias because of the individual's unobserved entophytes such as native ability (Wooldridge, 2003). Thus, we used the instrumental variable method to estimate the returns on education to control for bias related to unobserved abilities; the result was a return of $2.7 \%$. Additionally, to account for the self-selection bias introduced by workers' choosing education, we used the Heckman two-step method to estimate the returns on education. From the results of this model, it is clear that education affected laborers' participation in non-farm employment, even though the returns on education were reduced somewhat compared with the earnings model.

The returns on education in the western rural area were about $2.7-3.9 \%$ according to the three methods. These results show lower returns than the average value found in other studies of Chinese rural workers in recent years, likely due to the undeveloped regional economy and the lower educational levels in the western rural area.

Finally, we replaced the years of education with educational degree dummy variables in the earnings model. The results show that the returns on secondary education were 0.122 higher than those on secondary-level vocational education, indicating that secondary-level vocational education had a more beneficial effect on western rural laborers’ non-farm incomes.

${ }^{1}$ Heckman two-step method is based on the inverse mill ratio from a probit model to account for selection bias. The mathematical expression of the inverse mill ratio is $\lambda_{\mathrm{i}}=\phi\left(\alpha Z_{\mathrm{i}}\right) / \Phi\left(\alpha Z_{\mathrm{i}}\right)$, where $\phi$ and $\Phi$ are the probability density and cumulative distribution of normal distribution, respectively, and $\mathrm{Z}$ is the independent variable of the selection model. 
Table 1 The results for returns on education estimated by various methods

\begin{tabular}{|c|c|c|c|c|c|}
\hline \multirow{2}{*}{ Variables } & \multirow{2}{*}{ OLS } & \multirow[b]{2}{*}{ IV } & \multicolumn{2}{|c|}{$\begin{array}{l}\text { Heckman two-step } \\
\text { method }\end{array}$} & \multirow{3}{*}{$\begin{array}{l}\text { Educationa } \\
\text { l dummy } \\
\text { variables } \\
\text { regression }\end{array}$} \\
\hline & & & $\begin{array}{c}\text { Earning } \\
\text { model }\end{array}$ & $\begin{array}{l}\text { Selectio } \\
\text { n model }\end{array}$ & \\
\hline Years of education & $\begin{array}{c}0.039 * * * \\
(0.014)\end{array}$ & $\begin{array}{c}0.027^{* *} \\
(0.013)\end{array}$ & $\begin{array}{l}0.031 * * \\
(0.016)\end{array}$ & $\begin{array}{c}0.083^{* * *} \\
(0.009)\end{array}$ & \\
\hline $\begin{array}{l}\text { Secondary education } \\
(1=\text { yes, } 0=\text { no })\end{array}$ & & & & & $\begin{array}{c}0.336^{* *} \\
(0.155)\end{array}$ \\
\hline $\begin{array}{l}\text { Secondary-level vocational } \\
\text { education } \\
(1=\text { yes, } 0=\text { no })\end{array}$ & & & & & $\begin{array}{c}0.458^{* *} \\
(0.186)\end{array}$ \\
\hline $\begin{array}{l}\text { Gender } \\
(1=\text { male, } 0=\text { female })\end{array}$ & $\begin{array}{c}0.364 * * * \\
(0.073)\end{array}$ & $\begin{array}{c}0.299 \\
(0.589)\end{array}$ & $\begin{array}{c}0.283 * * * \\
(0.104)\end{array}$ & $\begin{array}{c}0.382 * * * \\
(0.067)\end{array}$ & $\begin{array}{c}0.351 * * * \\
(0.070)\end{array}$ \\
\hline Experience & $\begin{array}{l}0.027^{*} \\
(0.014)\end{array}$ & $\begin{array}{l}0.027^{*} \\
(0.013)\end{array}$ & $\begin{array}{c}0.036 * * * \\
(0.012)\end{array}$ & & $\begin{array}{c}0.034^{* *} \\
(0.014)\end{array}$ \\
\hline Squared experience & $\begin{array}{c}-0.001 * * \\
(0.000)\end{array}$ & $\begin{array}{l}-0.001 \\
(0.001)\end{array}$ & $\begin{array}{c}-0.001^{* *} \\
* \\
(0.000)\end{array}$ & & $\begin{array}{c}-0.001 * * * \\
(0.000)\end{array}$ \\
\hline $\begin{array}{l}\text { Married } \\
(1=\text { yes, } 0=\text { no })\end{array}$ & $\begin{array}{l}-0.034 \\
(0.035)\end{array}$ & $\begin{array}{c}0.235 \\
(0.249)\end{array}$ & $\begin{array}{c}0.128 \\
(0.093)\end{array}$ & $\begin{array}{l}-0.015^{*} \\
(0.008)\end{array}$ & $\begin{array}{l}-0.030 \\
(0.033)\end{array}$ \\
\hline $\begin{array}{l}\text { Health } \\
(1=\text { good, } 0=\text { poor })\end{array}$ & $\begin{array}{c}0.240 * * * \\
(0.021)\end{array}$ & $\begin{array}{l}0.277 * * * \\
(0.064)\end{array}$ & $\begin{array}{c}0.180 * * * \\
(0.014)\end{array}$ & $\begin{array}{c}0.477 * * * \\
(0.133)\end{array}$ & $\begin{array}{c}0.235 \\
(0.210)\end{array}$ \\
\hline Age & & & & $\begin{array}{c}* \\
(0.003)\end{array}$ & \\
\hline $\begin{array}{l}\text { Skill trained } \\
(1=\text { yes, } 0=\text { no })\end{array}$ & $\begin{array}{c}0.179 * * * \\
(0.056)\end{array}$ & $\begin{array}{c}0.350 \\
(0.355)\end{array}$ & $\begin{array}{l}0.214^{* *} \\
(0.112)\end{array}$ & $\begin{array}{c}0.727 * * * \\
(0.085)\end{array}$ & $\begin{array}{c}0.175^{* *} \\
(0.085)\end{array}$ \\
\hline Area of cultivated land & $\begin{array}{l}-0.015^{*} \\
(0.008)\end{array}$ & $\begin{array}{c}0.005 \\
(0.024)\end{array}$ & $\begin{array}{c}-0.014^{* *} \\
(0.007)\end{array}$ & $\begin{array}{l}-0.010 \\
(0.013)\end{array}$ & $\begin{array}{l}-0.015^{*} \\
(0.008)\end{array}$ \\
\hline $\begin{array}{l}\text { Number of family } \\
\text { members } \\
\text { Self-employed } \\
(1=\text { yes, } 0=\text { no })\end{array}$ & $\begin{array}{c}0.031 \\
(0.020) \\
0.307^{*} \\
(0.181)\end{array}$ & $\begin{array}{c}0.141 \\
(0.102) \\
0.160 \\
(0.546)\end{array}$ & $\begin{array}{l}0.020 \\
(0.017) \\
0.308^{*} \\
(0.169)\end{array}$ & $\begin{array}{c}0.034 * * \\
(0.014)\end{array}$ & $\begin{array}{c}0.030 \\
(0.020) \\
0.265 \\
(0.175)\end{array}$ \\
\hline $\begin{array}{l}\text { Other counties in home } \\
\text { province } \\
(1=\text { yes, } 0=\text { no })\end{array}$ & $\begin{array}{l}0.292^{*} \\
(0.158)\end{array}$ & $\begin{array}{c}0.389 \\
(0.404)\end{array}$ & $\begin{array}{l}0.283^{*} \\
(0.156)\end{array}$ & & $\begin{array}{c}0.388 * * * \\
(0.135)\end{array}$ \\
\hline $\begin{array}{l}\text { Eastern area } \\
(1=\text { yes, } 0=\text { no })\end{array}$ & $\begin{array}{c}0.480 * * * \\
(0.152)\end{array}$ & $\begin{array}{c}0.672 \\
(0.618)\end{array}$ & $\begin{array}{c}0.487 * * * \\
(0.143)\end{array}$ & & $\begin{array}{c}0.527 * * * \\
(0.161)\end{array}$ \\
\hline $\begin{array}{l}\text { Central area } \\
(1=\text { yes, } 0=\text { no })\end{array}$ & $\begin{array}{c}0.389 * * * \\
(0.098)\end{array}$ & $\begin{array}{l}0.609 * * \\
(0.299)\end{array}$ & $\begin{array}{c}0.391 * * * \\
(0.097)\end{array}$ & & $\begin{array}{c}0.364 * * * \\
(0.081)\end{array}$ \\
\hline $\begin{array}{l}\text { Western area } \\
(1=\text { yes, } 0=\text { no })\end{array}$ & $\begin{array}{c}0.315^{* * *} * \\
(0.109)\end{array}$ & $\begin{array}{c}0.573 \\
(0.687)\end{array}$ & $\begin{array}{c}0.309 * * * \\
(0.106)\end{array}$ & & $\begin{array}{c}0.218^{* *} \\
(0.088)\end{array}$ \\
\hline Vocational characteristics & controlled & controlled & $\begin{array}{c}\text { controlle } \\
\mathrm{d}\end{array}$ & & controlled \\
\hline County dummy variable & controlled & controlled & $\begin{array}{l}\text { controlle } \\
\mathrm{d} \\
-0.064^{* *}\end{array}$ & $\begin{array}{c}\text { controlle } \\
\text { d }\end{array}$ & controlled \\
\hline Inverse mill ratio & & & $\begin{array}{c}* \\
(0.020)\end{array}$ & & \\
\hline Constant te & $\begin{array}{c}6.120 * * * \\
(0.387)\end{array}$ & $\begin{array}{c}2.405 \\
(7.313)\end{array}$ & $\begin{array}{c}6.995 * * * \\
(0.354)\end{array}$ & $\begin{array}{l}-0.219 \\
(0.141)\end{array}$ & $\begin{array}{c}6.076^{* * * *} \\
(0.338)\end{array}$ \\
\hline
\end{tabular}

Note: We used the 2SLS method to estimate in the IV regression, where the instrumental variables were years of education of the individual's father and mother and the father's vocation. 


\section{Conclusion}

This paper provides a direct view of the effect of education on non-farm incomes in China's western rural area. We used the parametric method to estimate the returns on education and the P-S matching method to compare the treatment effects of secondary education and secondary-level vocational education while accounting for heterogeneity. The main conclusions of this paper are as follows: The returns on education in the western rural area range between $2.7 \%$ and $3.9 \%$ using various estimation methods in the Mincer earnings model. This result is lower than that found in most research on rural China, suggesting that education has less impact on human resources in western rural area mainly because of a shortage of educational quantity and quality.

Policy-related suggestions derived from this research are as follows: (1) Enhance investments in education in the western rural area. The government should pay attention to urban-rural integration in education and give political support to education in the western rural area, sending more excellent teachers there, designing a good rural school distribution, and relaxing the restrictions on moving from rural to urban places.

\section{References}

[1] De Brauw, A., and Rozelle, S. (2008). Reconciling the Returns to Education in Off - Farm Wage Employment in Rural China. Review of Development Economics, 12(1), 57-71.

[2] Wang Dewen, Cai Ffang, Zhang Guoqing. (2008) Employment and Wage Determination of Rural Migrant Workers:The Role of Education and Training. China Economic Quarterly, 7(4): $1131 \sim 1147$.

[3] Han Jun, and Guo J.(2007) An empirical study of China's rural education yields. Journal of Agro-technical Economics, 19(4): 4 7.

[4] CAO Z,, FU T.,and XU H. (2009). Assessing on the rate of return to education in the less developed regions__based on the field research of the four north-west provinces. Northwest Population Journal, 30(6): 27-36.

[5] Li, L., Wang, C., Segarra, E., and Nan, Z. (2013) "Migration, remittances, and agricultural productivity in small farming systems in Northwest China", China Agricultural Economic Review, Vol. 5 Iss: 1, pp.5 - 23.

[6] L. X., and Heckman, J. J. (2004). Heterogeneity, Selection Bias and the Return to Education: A Empirical Analysis Based on Chinese Micro-Data. Economic Research Journal, 4, 91 116. 